\title{
Ambidexterity as a Key Factor in Banks’ Performance: a Marketing Approach
}

Diego Monferrer (Ph.D., Universitat Jaume I) Associate Professor of Marketing, Business Administration and Marketing Department, Universitat Jaume I, Castellón, Spain,: dmonferr@uji.es.

Miguel Ángel Moliner (Ph.D., Universitat Jaume I) Full Professor of Marketing, Business Administration and Marketing Department, Universitat Jaume I, Castellón, Spain,: amoliner@uji.es.

Marta Estrada (Ph.D., Universitat Jaume I) Associate Professor of Marketing, Business Administration and Marketing Department, Universitat Jaume I, Castellón, Spain,: estrada@uji.es.

\section{Acknowledgments:}

The authors gratefully acknowledge financial support provided by the Ministry of Economy and Competitiveness of Spain via the research project "La confianza del consumidor respecto a la calidad de la relación y la orientación al mercado de las entidades financieras: los efectos de la crisis" (ECO2013-47134-P). 


\begin{abstract}
:
Based on an ambidexterity approach and using data from 384 Spanish bank branch managers, the results of this study confirm that market orientation facilitates the development of dynamic exploratory capabilities in bank branches and these, in turn, influence their capacity to exploit knowledge through marketing capabilities, leading to higher performance. The findings provide researchers and managers with practical insights into the joint application of certain key approaches and theories (market orientation, ambidexterity, resources and capabilities based view and dynamic capabilities theory) in order to guarantee the sustainable performance of service firms in general, and banks in particular, especially in a context of crisis.
\end{abstract}

Keywords: Ambidexterity, Market orientation, Marketing capabilities, Dynamic capabilities, Performance. 


\section{AMBIDEXTERITY AS A KEY FACTOR IN LEAVING THE CRISIS BEHIND}

The world crisis that began in 2008, with a particular impact on the financial sector in the most developed countries, has undoubtedly affected consumer attitudes and behaviours (Hansen 2014; Johnson and Peterson 2014; Kaytaz and Gul 2014; Monferrer et al. 2016). The most obvious consequence has been the loss of trust in financial institutions, as pointed out by the Marketing Science Institute (MSI 2011). One country that has suffered particularly from this crisis is Spain (Ruiz et al. 2014; Martí and Pérez 2015), whose banking system received a financial bailout of a hundred billion euros from the European Union in June 2012. These events offered researchers an exceptional opportunity to study the impact of the crisis through a microeconomic approach, especially to analyse customer behaviour during this time. In fact, one of the seven research priorities for 2012-2014 identified by the Marketing Science Institute (MSI) was to study the effects of the crisis on trust in financial institutions (Deighton et al. 2012). As a result, several studies have recently demonstrated the negative effect of the crisis on bank credibility, and the erosion of customers' trust in their banks (Hansen 2014; Johnson and Peterson 2014; Kaytaz and Gul 2014; Gijsenberg et al. 2015; Martí and Pérez 2015; Monferrer et al. 2016).

In this context of far-reaching changes in the conditions affecting the financial business environment, and having come through the worst moments of the crisis, it is surprising that most of the literature has focused on the negative effects of the crisis (Hansen 2014; Johnson and Peterson 2014; Kaytaz and Gul 2014; Gijsenberg et al. 2015; Martí and Pérez 2015). However, there is a clear lack of research taking a positive approach by proposing courses of action for banks. Such proposals will help banks to identify crucial factors on which to reorientate their efforts to turn an unfavourable situation around and focus on recovering competitiveness and improving performance (Lettice et al. 2014; Makkonen et al. 2014; Monferrer et al. 2016).

On this question, a general review of the marketing literature reveals certain theoretical approaches that are largely used in isolation to explain firms' competitiveness and performance. On the one hand, there are theoretical approaches associated with efficiency-based models (Teece et al. 1997; Newbert 2007; Wu 2010), such as the resources and capabilities based view from a marketing perspective (Chahal and Kaur 2014; Fang et al. 2014; Kamboj and Rahman 2015) and dynamic capabilities theory 
(Lidija and Robert 2014; Jiang et al. 2015; Schweizer et al. 2015), both of which are based on different types of resources and capabilities, substantive and dynamic, that firms generate. On the other hand are approaches on the strategic orientations firms adopt in their conceptions of their customer services, the main one being the market orientation from the marketing discipline (Shoham et al. 2005; Grinstein 2008; Kwon 2010; Zhang and Duan 2010; Liu et al. 2017; Al Mamun et al. 2018). However, although previous research has demonstrated the effects on performance of constructs linked to these theoretical perspectives, to our knowledge no studies have yet considered these perspectives jointly, nor therefore, how these variables might interrelate, in a reasoned theoretical framework, to directly or indirectly contribute to improving performance (Monferrer et al. 2015). Against this background, the present study draws on ambidexterity theory, based on firms' simultaneous development of a dual exploration/exploitation function (Fiset and Dostaler 2013; Eltantawy 2016), as an integrating theoretical perspective with which to jointly analyse the specific effects of the following variables: market orientation, marketing capabilities and dynamic capabilities. The study views the firm through a micro-level lens where, instead of senior managers, the focus is on branch managers, who have a close perception of and make a direct contribution to the way the relationship with customers is nurtured (Davidsson 2004; Schlosser and McNaughton 2007). This approach has been used in previous research such as Moliner et al. (2018).

The present study makes some significant theoretical and practical contributions. It aims to respond to recent calls in the literature for new research to enhance understanding of the main gaps associated with ambidexterity theory, which largely concern the lack of a holistic view of the most relevant theoretical approaches of business competitiveness, in an innovative analytical context that to date has not been explored in the literature. Drawing on this idea, we identify the interrelated facts among these key factors (market orientation, marketing capabilities and dynamic capabilities), which may be crucial to the recovery of a sector that the data suggest is experiencing considerable difficulties in maintaining its commercial dynamism with the customer, and therefore its competitive sustainability. The paper is organised as follows. The next section describes the theoretical context underlying the hypotheses for the model of the influence bank branch market orientation has on ambidexterity capabilities as determinants of branch performance. The empirical study conducted to test the model is 
then presented, together with an analysis of the results. The paper ends with the main conclusions, limitations and future lines of research.

\section{AN APPROACH TO AMBIDEXTERITY THEORY}

Fiset and Dostaler (2013) identify Duncan (1976) as the first author to coin the term ambidexterity in the organisational field. This author uses the term to describe the introduction of organisational structures to balance the conflicting objectives of remaining aligned, that is, maintaining coherence across current activity patterns, and adaptable, that is, allowing activities to be quickly reconfigured to meet changing environmental demands. Later, in one of the most influential papers in this research stream March (1991) defines the ambidextrous organisation as one that is capable of using knowledge to manage its present activity efficiently (exploitation capacity), while simultaneously developing the necessary flexibility to generate knowledge designed to take advantage of new opportunities arising in the environment (exploration capability). Hence, if an organisation focuses on only one of these activities at the expense of the other, it will inevitably suffer problems and tensions that will prevent it from carrying out its activity sustainably (Judge and Blocker 2008; Kouropalatis et al. 2012;

Eltantawy 2016).

For this reason, although exploration and exploitation have traditionally been considered as types of organisational learning based on different configurations of knowledge flows, each one with different associated costs and benefits (March 1991, 2006), organisational learning research has emphasised the need to reconcile the implicit tension underlying these two processes of knowledge management in the organisation (March 1991, 2006; Tushman and O’Reilly 1996; Benner and Tushman 2003;

Kouropalatis et al. 2012; Eltantawy 2016). Within this idea, ambidexterity starts from the premise that organisations capable of reconciling the exploration/exploitation paradox - or put another way, capable of exploiting their knowledge and, at the same time, exploring new domains - will be able to generate organisational results sustainably (Judge and Blocker 2008; Kouropalatis et al. 2012). In consequence, recent studies advocating the reconciliation of exploration and exploitation are manifold (Ho et al. 2011; Kouropalatis et al. 2012; Lee and Huang 2012; Fiset and Dostaler 2013; Carter 2015; Torres et al. 2015; Zacher and Rosing 2015; Eltantawy 2016; Lee and Rha 2016). 
Following this logic, organisations should attempt to develop mechanisms and behaviours that enable them to be ambidextrous as an essential part of their strategy to achieve sustainable performance over time. There is an implicit question in this assumption, however: how does an organisation become ambidextrous? Recent interest in answering this question is helping to refine and extend the concept of ambidexterity (Judge and Blocker 2008; Raisch et al. 2009; Ho et al. 2011; Eltantawy 2016) and suggests different ways for an organisation to arrive at this approach.

First, pioneering authors such as Duncan (1976), and later Tushman and O'Reilly (1996), have argued that to be ambidextrous, organisations need to create dual structures based on spatial differentiation and separation between units focusing on exploration (to stimulate innovation with an eye to the future), and units focusing on exploitation (to efficiently bring these innovations to the market). This organisational division has been termed structural ambidexterity (Duncan 1976; Tushman and O’Reilly 1996; Benner and Tushman 2003; Fiset and Dostaler 2013).

However, there is debate in the literature on the complexities involved in having groups or units that pursue diverging objectives in the same company (Fiset and Dostaler 2013). Following this line of debate, a second research stream argues that firms can resolve this difficulty by combining diverging characteristics in the same contextually ambidextrous unit (Jansen et al. 2005; Fiset and Dostaler 2013). Gibson and Birkinshaw (2004) hold that contextual ambidexterity allows individuals in different company units to resolve conflicting demands in idiosyncratic ways. Unlike its structural equivalent, contextual ambidexterity is not based on separate units to manage opposing objectives. On the contrary, the objectives of alignment and adaptability can be managed simultaneously by each employee if favourable frameworks are developed, based on strong social relationships between work colleagues (Gibson and Birkinshaw 2004; Jansen et al. 2006). To summarise, this contextual ambidexterity research stream proposes and examines the application of specific structural and social tactics that guarantee efficient management of the tensions inherent in exploration and exploitation (Kouropalatis et al. 2012; Fiset and Dostaler 2013; Carter 2015) and recognises the need for managers and employees with ambidextrous profiles, that is, sufficient initiative to explore new opportunities for the future, as well as the capacity to contribute in exploiting current commitments (Jansen et al. 2009; Fiset and Dostaler 2013; Lee and Rha 2016). 
However, although this debate is largely resolved, a new one has arisen. Despite some contributions from a general perspective (Jansen et al. 2005; Judge and Blocker 2008; Li et al. 2008; Chang et al. 2011; Lee and Huang 2012; Torres et al. 2015), authors such as Judge and Blocker (2008), Raisch et al. (2009) or Chang et al. (2011) note that it is still a challenge for most organisations to reach the point of adopting and implementing an ambidextrous approach, and therefore deserves deeper conceptual and empirical analysis in the specialised literature (Monferrer et al. 2015).

In sum, the challenges that guide this study on ambidexterity theory are related to (1) determining the antecedent strategic contexts on which to develop the dual exploration/exploitation function, and (2) identifying the specific capabilities that enable this dual function to be met with a view to improving firms' performance, as shown in Figure 1.

Place Figure 1 about here

In addition, the foundations and assumptions underlying ambidexterity theory have been analysed and applied almost exclusively in technology-intensive and innovation-intensive firms (Ho et al. 2011; Kouropalatis et al. 2012; Lee and Huang 2012; Fiset and Dostaler 2013; Torres et al. 2015; Zacher and Rosing 2015; Lee and Rha 2016). This research has examined the coexistence of exploitation and exploration in terms of R\&D units (McCarthy and Gordon 2011) and certain key factors such as technological innovation (Raisch et al. 2009) or new product development (Atuahene-Gima and Murray 2007). In this vein, we argue that the principles of ambidexterity should not be exclusively applied in firms whose activity requires permanent technological renovation, innovation and creation. Indeed, the financial crisis in the world's markets, and its attendant need for profound adaptation, renovation and restructuring of the traditional mechanisms in a large number of sectors, offer a clear opportunity to extend the study of ambidexterity into other hitherto unexplored and less radical contexts. Service sectors in general, and the banking sector in particular, are fitting examples. 


\section{HYPOTHESES DEVELOPMENT}

\section{Market Orientation as an Antecedent Contextual Unit for Applying the Ambidextrous}

\section{Approach}

Market orientation is now firmly established as a central construct in the marketing literature (Theodosiou et al. 2012). Traditionally, the vast majority of studies have explored market orientation from either a behavioural or a cultural perspective. The behavioural perspective highlights specific activities related to the generation and dissemination of and responsiveness to market intelligence (Kohli and Jaworski 1990). In turn, the cultural perspective focuses on the organisational norms and values that encourage behaviours consistent with intense attention to customers, competitors and the environment (Narver and Slater 1990). However, many authors advocate an eclectic consideration of the two perspectives, which they consider to be perfectly complementary (Kolar 2006; Zhou et al. 2008).

This combined viewpoint understands market orientation as a strategic orientation for managing market knowledge grounded on the organisation's firm commitment to develop a set of processes, beliefs and values that reflect the fundamental principle of marketing (Kohli and Jaworski 1990; Narver and Slater 1990). This principle is that all decisions taken in the firm begin with the customer and are based on a deep and shared understanding of their needs and behaviours, with the aim of outperforming their competitors (Kolar 2006; Theodosiou et al. 2012; Fang et al. 2014). To achieve this, a market orientation must lead the organisation to identify and construct differentiating capacities in order to satisfy customers and give them superior value (Theodosiou et al. 2012).

Based on this conceptualisation, various studies find that market-oriented mechanisms can be key factors in firms' capabilities to implement routine actions concerning their present market and, at the same time, develop new actions aimed at both present and emerging markets (Atuahene-Gima 2005; Li et al. 2008). In fact, seminal authors on the market orientation construct (Kohli and Jaworski 1990; Narver and Slater 1990) updated their original static models to include these two aspects. Kohli and Jaworski's (1990) original model was extended by Jaworski et al. (2000), who suggested that there are two complementary approaches in the notion of market orientation: the "market-driven" approach and the "market-driving" approach. "Market-driven" means taking advantage of the present conditions by 
providing responses within a given market structure; in contrast, "market-driving" refers to changing the rules of the competitive game, being able to alter them through the search for and implementation of new products, business models or value generating elements (Li et al. 2008; Monferrer 2011). In the same line, Narver et al. (2004) state that a market orientation should consider two intrinsic approaches in its dimensions: a reactive approach (associated with the "market driven" idea) with an emphasis on real markets; and a proactive approach (associated with the "market driving" idea) focusing on latent markets. The reactive aspect of market orientation is related to the generation, diffusion and response capacity of market information in relation to current products and markets, and addresses customers' express needs (Atuahene-Gima 2005; Li et al. 2008). The proactive side of market orientation highlights the discovery of latent and/or emerging customer needs through market exploration and analysis to find new opportunities, hence recognising the value of renewing products or services.

However, despite this updating of the seminal models, the literature continues to take a single perspective to analyse the antecedent role of market orientation in the internal development and generation of capabilities (Li et al. 2008). Moreover, as with research based on the premises of ambidexterity theory, these studies have largely focused on technology-intensive manufacturing sectors, which has recently led to a call for further research in clearly differentiated sectors, particularly service sectors (Lettice et al. 2014; Kazakov 2016; Hinson et al. 2017; Salehzadeh et al. 2017; Zebal 2018).

The research context for the present study - the financial sector analysed at the micro-level of the branch - is immersed in a landscape of profound competitive upheaval, the effects of which have been amplified by the recent financial crisis. This context therefore offers an ideal framework in which to respond to the abovementioned recent calls. On this basis, our study considers that the dual reactive/proactive aspect of market orientation is conceptually associated with the dual exploitative/exploratory side undergirding the pillars of ambidexterity (O'Reilly and Tushman 2004; Li et al. 2008).

First, the bank's institutionalised market orientation means that all its employees share a common customer-centred view (Fang et al. 2014). In line with the basic assumptions of uncertainty reduction 
theory (Berger 1979), this shared strategic orientation means that managers and employees are guided by a common pattern of behaviour and will come to an agreed understanding of the norms, mechanisms and processes proposed by the bank. Because this process reduces the uncertainty associated with implementing these proposals, they will be able to concentrate on exploiting the firm's present value, associated with knowledge about existing market segments and products (Li et al. 2008)

Exploitation capabilities faithfully represent this reactive function of the branch. Specifically, these capabilities should help to satisfy the needs of present customers by improving established actions, expanding existing products and services, and raising efficiency of the present distribution channels (Jansen et al., 2006). These capabilities include operative skills linked to the execution, implementation and exploitation of resources ( $\mathrm{Li}$ et al. 2008).

Second, adopting a strategic orientation based on managing market knowledge allows the bank branch to create the mechanisms it needs to develop an open mindset with which to break down barriers and inflexibilities by removing obsolete perspectives, systems and procedures, and incorporating new formulas for doing business with its customers (Atuahene-Gima 2005).

In this case exploration capabilities serve this function. Specifically, exploration capabilities involve generating new knowledge or removing some existing knowledge as a result of the search for new organisational routines, and discovering fresh approaches to technology, business, processes and products (McGrath 2001; Jansen et al. 2006). In other words, they involve skills related to searching, adaptation, flexibility, assuming risks and innovation (Li et al. 2008).

\section{Market Orientation in the Branch as the Generator of Ambidextrous Marketing and Dynamic}

\section{Capabilities}

Having recognised the antecedent influence of market orientation on the adaptation of exploration and exploitation capabilities, we must now consider the question of what specific capabilities will enable this dual function to be carried out in bank branches. To answer, we draw on two of the most representative strategic explanatory models of company competitiveness in the literature: efficiencybased models (Teece et al. 1997; Newbert 2007; Wu 2010) from the resources and capabilities based view, and the theory of dynamic capabilities. These two complementary models advocate 
differentiating between two types of capability: substantive capabilities and dynamic capabilities.

Zahra et al. (2006) draw on the evolutionary theory of the firm to explain the difference between these two capabilities (Nelson and Winter 1982), taking three elements into account: (1) the set of skills the firm uses to solve a problem or achieve a specific aim (substantive capability); (2) the presence of a dynamic environment that radically changes the problems to be tackled and the objectives pursued (the present financial crisis is a clear example); and (3) the dynamic skill to change or reconfigure existing substantive capabilities (dynamic capability).

Hence, substantive operational capabilities help to maintain an aptitude of functionality and of providing customers a service in the branch by ensuring its day-to-day efficiency, and represent the exploitative nature of the capability. Given that the relevance of substantive capabilities lies in integrating resources and capabilities in line with the firm's strategic management (Wang and Ahmen 2007), we identify marketing capabilities as core functional capabilities in organisations committed to adopting a strategic market orientation (Tsai and Shih 2004). Undoubtedly, through certain product/service, pricing, channel management and communication actions, marketing capabilities enable the direct operationalisation of the strategic approach linked to market knowledge management and satisfying customer needs on which the market orientation is grounded (Vorhies and Morgan 2005).

In turn, strategic dynamic capabilities help the firm to maintain its aptitude to evolve through capabilities of adaptation, absorption and innovation, allowing it to create, extend and modify, transform and reconfigure its substantive capabilities, and thereby encouraging an attitude of sustainable competition (Eisenhardt and Martin 2000; Teece 2007; Wang and Ahmed 2007; Hou 2008; Lidija and Robert 2014; Jiang et al. 2015; Schweizer et al. 2015). By definition, therefore, dynamic capabilities cover the exploratory nature of the capability. In sum, drawing on contingency theory (Hofer 1975; Venkatraman 1989), the strategic behaviours designed to improve bank branch performance are based on the fit between the situations in the internal and external environments (Makkonen et al. 2014). Put another way, the effectiveness of a market orientation in improving bank branch performance will depend on the optimal conditions being in place to implement this orientation. In the current external situation of instability generated by the 
crisis and its negative repercussions on customer confidence, banks must develop internal mechanisms that allow them to exploit their substantive capabilities to the full, and at the same time renew and adapt to face the new prevailing conditions in the present business context. That is, branches must be able to channel strategic knowledge generated from adopting a market orientation (grounded on the dual proactive/reactive premise) to develop the key capabilities that will allow them this dual ambidextrous function of exploration/exploitation: dynamic and marketing capabilities, respectively. These arguments lead us to propose the following hypotheses:

\section{H1. Market orientation relates directly (and positively) to exploitative marketing capabilities at} bank branch level.

H2. Market orientation relates directly (and positively) to explorative dynamic capabilities at bank branch level.

\section{Ambidextrous Capabilities and their Influence on Branch Performance}

Capabilities represent a set of knowledge, experiences and skills needed to develop a task or activity, and involve complex patterns of coordination and cooperation among individuals and resources (Grant 1996). This concept highlights the determinant role of a firm's capabilities in its performance (Penrose 1959; Rumelt 1984; Teece 1984; Wernerfelt 1984). In fact, it is generally accepted that firms may perform differently because they use substantive capabilities in different ways (Hult and Ketchen 2001; Hooley et al. 2005; Ha-Brookshire and Dyer 2009).

However, not all organisational capabilities will be sources of superior performance for the firm (Day 1994). Depending on how valuable, rare, and difficult to imitate or substitute these capabilities are criteria that determine their substantive nature - the firm will be able to achieve better performance through actions by creating superior value that is difficult for their competitors to counter (Wernerfelt 1984; Grant 1996; Teece et al. 1997; Ray et al. 2004; Newbert 2007; Wu 2010; Monferrer 2011). On this question, over the last two decades numerous studies have identified marketing capabilities as a source for increasing competitiveness and performance (Guenzi and Troilo 2006; Krasnikov and Jayachandran 2008; Morgan et al. 2009; Vorhies et al. 2009; Nath et al. 2010; Murray et al. 2011; Theodosiou et al. 2012; Fang et al. 2014; Kamboj and Rahman 2015). Marketing capabilities have been defined as "the integrative processes designed to apply collective knowledge, skills and resources 
of the firm to market-related needs of the business, enabling the business to add value to its goods and services, adapt to market conditions, take advantage of market opportunities and meet competitive threats" (Vorhies 1998: 4). By leveraging the resources and capabilities based view of the firm, marketing researchers have demonstrated that marketing capabilities can help create a competitive advantage because they may be rare, difficult to achieve, difficult to duplicate and their value can be appropriated by the firm, or in this case the bank branch (Vorhies et al. 1999; Hooley et al. 2005). Marketing capabilities are valuable because they enable firms to determine not only their customers' needs, but those of all the other agents in the channel as well; and also because they allow firms to respond to competitors' actions well in advance in order to grasp opportunities and overcome threats (Vorhies and Morgan 2005; Chahal and Kaur 2014; Fang et al. 2014). Similarly, marketing capabilities are rare and inimitable as they are developed by the branch itself through the knowledge and skills of its employees and cannot be copied. Further, employees' skills are also consistently enhanced through learning and experience, that is, by repeatedly applying their knowledge to solve the branch's marketing problem (Tsai and Shih 2004). Manan and Jan (2010) also noted that marketing capabilities are irreplaceable. Since marketing capabilities are a combination of varied resources, it becomes difficult for a branch to replace them with other resources that could provide the same result (Vorhies and Morgan 2005).

Specifically, from an operational approach, marketing capabilities comprise pricing, marketing products/services, efficient channel management, promotional capabilities and customer service delivery (Vorhies and Morgan 2005; Morgan et al. 2009). Pricing capabilities refer to the branch's ability to effectively manage its pricing offers to the market in response to the movements and tactics implemented by competitors in this field. Products/services marketing concerns the branch's ability to successfully incorporate and market novel products/services offered to meet rapidly changing environmental conditions and customer preferences (Song et al. 2005). Efficient channel management involves simplifying potential problems associated with the logistic integration between branches and the bank, and designing and capitalising on the most appropriate service distribution channels. Finally, promotional capability is related to managing customer expectation and perceived image and value (Vorhies and Morgan 2005). 
In sum, by developing marketing capabilities in the branches themselves, the actions they implement are grounded on a perfect fit between the external conditions associated with the market opportunities detected, and the internal availability of key resources and capabilities to take advantage of them (Makkonen et al. 2014). Based on this premise, products/services can be effectively delivered to the final customers, who perceive them as unique elements of value, thus favouring superior organisational performance (Hult and Ketchen 2001; Guenzi and Troilo 2006; Krasnikov and Jayachandran 2008; Morgan et al. 2009; Vorhies et al. 2009; Nath et al. 2010; Murray et al. 2011; Theodosiou et al. 2012; Chahal and Kaur 2014; Fang et al. 2014; Kamboj and Rahman 2015). This idea leads to the third research hypothesis:

H3. Exploitative marketing capabilities relate directly (and positively) to bank branch short-term performance.

As noted above, not all the bank branch's organisational capabilities will generate superior performance (Day 1994). Indeed, highly unpredictable, changing and dynamic crisis contexts such as the present one, with continual changes in technology, consumer tastes and market characteristics, can erode the value of the substantive capabilities underlying competitiveness in branches, making them obsolete, irrelevant or ineffective in the short term (Judge and Blocker 2008; Liao et al. 2011; Zhou and Li 2010; Carter 2015). As a result, today, the implications for performance of any organisational process are subject to significant causal ambiguity (Lidija and Robert 2014; Jiang et al. 2015; Monferrer at al. 2015; Schweizer et al. 2015). Thus, by deliberately choosing to make a greater cognitive effort to develop the marketing capabilities that allow them to exploit market intelligence, market-oriented branches can partially overcome this ambiguity in the short term. However, as Zollo and Winter (2002) argue, this greater cognitive effort must be accompanied by developing exploration skills in order to adapt to and match existing substantive capabilities, or deal with profound changes in these capabilities. The literature terms these skills dynamic capabilities, and they appear to reflect precisely the evolutionary nature of resources and capabilities and, therefore, complete and update some basic assumptions from the resources and capabilities based view that conceptualised firms' competitiveness from a static and internal position (Teece et al. 1997; Eisenhardt and Martin 2000; 
Zahra and George 2002; Zollo and Winter 2002; Zahra et al. 2006; Wang and Ahmed 2007; Hou 2008; Monferrer 2011).

Hence, in a turbulent market environment like the present one, possessing and accumulating valuable organisational capabilities such as marketing capabilities is a necessary but insufficient factor to guarantee bank branches' continued and sustainable performance (Wang et al. 2007; Hou 2008). Furthermore, in order to maintain the value, rarity, inimitability and irreplaceability of these operative capabilities over time, they must generate certain strategic and exploratory dynamic capabilities (Eisenhardt and Martin 2000; Teece 2007; Helfat et al. 2007; Lidija and Robert 2014; Jiang et al. 2015; Schweizer et al. 2015; Lee and Rha 2016). Specifically, Wang and Ahmed (2007) and Monferrer (2011) identified adaptive, absorptive, and innovative capabilities as three main factors of dynamic capability. Adaptive capability is the ability to identify potential market opportunities and react flexibly to them; absorptive capability is the ability to learn from partners, integrate external information and transform it into firm-embedded knowledge; and, innovative capability is the ability to develop new products and/or markets through alignment of strategic innovative orientation with innovative processes (Tseng and Lee 2014).

The contribution these dynamic capabilities make to branch performance should be clearly differentiated from that made by substantive marketing capabilities since the two are associated with completely different spheres of application and time horizons. Exploitative and operational marketing capabilities are associated with efficiency, alignment, execution and implementation, and help to maintain the branch's technical aptitude for serving and satisfying customers in their day-to-day business, thus improving organisational performance in the short term. In turn, explorative and strategic dynamic capabilities are associated with search, analysis, adaptation and flexibility, and help to maintain the firm's aptitude to evolve by facilitating the creation, extension and modification of its substantive resources and capabilities (Lidija and Robert 2014; Jiang et al. 2015; Schweizer et al. 2015; Zacher and Rosing 2015; Eltantawy 2016; Lee and Rha 2016). Therefore, these dynamic capabilities cannot have a direct effect on short-term performance in bank branches since they are designed to achieve long-term performance (Teece 2007; Kouropalatis et al. 2012; Monferrer et al. 2015). We therefore hypothesise that: 


\section{H4. Explorative dynamic capabilities do not relate directly to bank branch short-term}

performance.

Instead, dynamic capabilities will contribute to performance indirectly through the positive effect they have on maintaining the competitive and substantive nature of branches' marketing capabilities. In fact, at the end of the last century Zahra (1999) claimed that sustained investment in creating dynamic capabilities would become one of the main sources of successful competitiveness in the twenty-first century, since although dynamic capabilities would not be sufficient to guarantee improved performance, they would be necessary to explain these superior results (Zhou and Li 2010). In a later paper, and at a general level, Zahra et al. (2006) define the terms of substantive and dynamic capabilities, theoretically considering the existence of a relationship of dependence between the two that would extend understanding of how they contribute to performance. Specifically, when an organisation systematically and proactively learns about changes affecting its customers, competitors and the macro-environment, it can gather valuable knowledge about the market and design better operational interventions for its products and services in its target markets. This leads to improved performance because customers have higher purchase intention and are more satisfied (Fang et al. 2014). From the perspective of ambidexterity, the same direction in the relation is also supported theoretically: exploitation involves a second phase where new knowledge acquired through exploration is applied to improve the organisation's activity.

This argument contributes to the specialised literature because studies analysing the effect of organisational capabilities on firm performance have not traditionally explored the differing nature of these capabilities and the consequent interrelationship that may exist between them (Monferrer et al. 2015), which provides the basis for our final hypothesis:

H5. Explorative dynamic capabilities relate directly (and positively) to exploitative marketing capabilities at bank branch level.

Figure 2 shows the model to be analysed.

Place Figure 2 about here 


\section{METHOD}

\section{Sample Selection and Data Collection}

The research team signed a collaboration agreement with a major Spanish bank (one of the top six firms based on total assets according to Moody's international rating agency), through which we were able to interview branch managers for this study. The universe for the study was 530 bank branches in three Spanish regions: Valencian Community, Murcia and the Balearic Islands.

To design a questionnaire that closely matched the reality of the firm, several group activities were carried out with senior marketing managers at the bank, including discussions on the role of physical branches in guaranteeing banks' overall competitiveness and attempting to identify the key factors to be strengthened at the branch level to this end. The theoretical approach taken in the study was therefore agreed and confirmed at first hand from the business perspective. In addition, the final questionnaire items were pre-tested through 25 personal interviews with bank branch managers in October 2014. Then an electronic version of the questionnaire was prepared for the field work, carried out in December 2014 and January 2015, which yielded 384 valid responses (72.45\% of the total). A sampling error of \pm 2.60 percent was assumed for a confidence level of 95.5 percent.

Of the total responses obtained, the average number of employees per bank branch was between five and six (59.2\% of the branches had between 2 and 5 employees; $34.5 \%$ between 6 and 10 employees and only $6.3 \%$ had more than 10 employees). By branch type, 108 were firmly established branches (28.1\%), 124 were in small locations (32.4\%), 57 were in medium-sized locations (14.8\%), 52 were in urban locations (13.8\%) and 41 were branches for foreign customers (10.7\%).

\section{Measurement Instruments}

All the scales used to measure the constructs correspond to their theoretical definitions. In all cases, we adapted scales that other authors had already tested in previous studies, tailored to the bank branch context. The questionnaire items were all closed attitudinal questions measured on a five-point Likert scale, where 1 represented the lowest agreement with the statement (completely disagree), and 5 the highest (completely agree). Table 1 provides a summary of the sources of the measurement scales, which are presented later in the paper in Table 2. 
To measure the market orientation of the branches analysed we used the multidimensional scale proposed by Kolar (2006), designed in the banking context and consisting of four dimensions covering the behavioural and cultural perspectives associated with the construct (Kohli and Jaworski 1990; Narver and Slater 1990): intelligence generation (three items), intelligence dissemination (four items), responsiveness (four items) and marketing culture (four items).

A three-dimensional instrument was used to measure the three essential dynamic capabilities identified in the specialised literature (Eisenhardt and Martin 2000; Wang and Ahmed 2007; Hou 2008): adaptive, absorptive and innovative capabilities. Specifically, adaptive dynamic capability was measured on the three-item scale proposed by Gibson and Brikinshaw (2004), absorptive dynamic capability was measured with the three-item scale proposed by Chen et al. (2009), and an adaptation of the five-item scale proposed by Akman and Yilmaz (2008) was used to measure innovative dynamic capability.

Marketing capabilities were measured with a version adapted from Vorhies and Morgan's (2005) multidimensional scale, for which four dimensions were identified based on the different capability typologies: pricing (three items), commercialisation of products/services (three items), channel management (four items), and communication (six items).

Finally, there is no consensus in the economic and business literatures on how to measure performance (March and Sutton 1997; Richard et al. 2009; Silvestro 2014; Vij and Bedi 2016). Business performance is usually evaluated by either objective or subjective measures. In the specific context of bank branches, objective indicators may be of little use for comparative purposes due to marked differences in factors such as competition, turnover, market structure or customer type among the branches analysed. In contexts of analysis such as this one, most researchers use subjective measures to evaluate business performance (Naman and Slevin 1993; Jarvis et al. 2000; Wiklund and Shepherd 2005; Wall et al. 2004; Wood 2006; Ellis 2006; Clercq et al. 2010; Kraus et al. 2012; Santos and Brito 2012; Moliner et al. 2018). Furthermore, there is evidence for positive correlations between subjective and objective measures (Dess and Robinson 1984; Pearce et al. 1987; Venkatraman and Ramanujam 1987; Covin et al. 1994; Shoham 1998; Styles 1998; Dawes 1999; Wall et al. 2004; Vij and Bedi 2016). These arguments appear to support the use of subjective measures to evaluate bank branch 
performance. We therefore apply an adaptation of the scale proposed by Jantunen et al. (2008) to measure performance, which has been used previously in other studies in the banking context (Moliner et al. 2018). On the basis of this scale, bank branch managers were asked to indicate their degree of satisfaction with the results for the following aspects of their activity: turnover, market share, profitability and global satisfaction. The general nature of these measurements means that their applicability should not differ, nor should they be subject to any influences from sample characteristics or other variables in the proposed model (Jantunen et al. 2008; Moliner et al. 2018).

Place Table 1 about here

\section{Validity and Scale Reliability}

Confirmatory factor analysis was run using structural equation modelling to refine the scales with version 6.1 of the EQS multivariate software package. The parameters were estimated using the maximum likelihood approach and the model development strategy (Hair et al. 2009). Thus, based on latent variable structures assumed for the different constructs, the initial models were refined by suppressing the least appropriate indicators.

To this end we examined first the estimation parameters following Jöreskog and Sörbom's (1993) recommendations. Indicators that did not satisfy the strong convergence condition, with standardised coefficients $(\lambda)$ under 0.6, were withdrawn (Steenkamp and Van Trijp 1991; Hair et al. 2009). Then compliance with the weak convergence condition was verified (Steenkamp and Van Trijp 1991) by analysing the significance of the factor regression coefficients between indicators and their corresponding latent variables. This was done by revising the Student t value imposing the maximum requirement $(\mathrm{t}>2.58 ; \mathrm{P}=0.01)$. Finally, evolution of the main model fit measurements was monitored as the indicators were removed. Through this process the indicators GEN.2 from the intelligence generation scale, RES.3 from the responsiveness scale and PRI.2 from the pricing capability scale were eliminated as they did not satisfy the strong convergence condition (with standardised coefficients $(\lambda)$ of $0.523,0.500$ and 0.529 , respectively). Removing these indicators does not affect the conceptual essence of each construct considered. 
Several tests were then run to verify whether the refinement process following the above tests had negatively affected scale reliability. Internal consistency was tested with Cronbach's alpha, and construct composite reliability and analysis of variance extracted tests were applied (Churchill 1979; Nunnally 1979). Convergent and discriminant validity were then analysed. Convergent validity was verified by returning to the confirmatory factor analysis performed at the start of the process and observing the estimated value and significance of the correlations between the dimensions in both scales. These correlations were relatively high and significant and therefore sufficient guarantee of convergent validity. A summary of the results after the factor, reliability and validity tests is shown in Table 2.

Place Table 2 about here

Table 3 shows the discriminant validity of the constructs considered, evaluated through AVE (Fornell and Larcker 1981). For discriminant validity, a construct must share more variance with its indicators than with other constructs of the model. When the square root of the AVE between each pair of factors is higher than the estimated correlation between those factors, as in our case, discriminant validity is ratified.

Place Table 3 about here

Further tests were also carried out. First, we checked for signs of multicollinearity by testing the variance inflation factor (VIF) among latent variables in our proposed overall model. Values were below 10 (Myers 1990; Hair et al. 2009), suggesting multicollinearity was not an issue in our study. Second, a t-test of independent means was performed on the dimensions of the variables in the proposed model. This test was conducted using the first 45 and last 45 respondents. No significant differences were found between these respondents at the 0.05 level, indicating an absence of nonresponse bias (Armstrong and Overton 1977). Third, various ANOVA were run to confirm that sample characteristics do not affect the model constructs. The control variables were location, branch 
typology and number of employees. Results revealed no significant differences in any of the analyses. Finally, Harman's (1976) test was run to check for common method variance bias, concluding that the bias caused by the method used did not affect the validity of the results obtained when the hypotheses were tested (Podsakoff et al. 2003; Friedrich et al. 2009).

\section{RESULTS}

Again, the hypotheses were tested using structural equations models with EQS 6.1 software; the results are shown in Table 4. All the hypotheses were confirmed. We can therefore verify that the market orientation bank branches adopt generates an optimal strategic context for simultaneously fostering key capabilities in the development and implementation of an ambidextrous approach in the branch: exploratory dynamic capabilities $\left(\mathrm{H}_{1}: \lambda=0.674 ; \mathrm{t}=8.162\right)$ and exploitative marketing capabilities $\left(\mathrm{H}_{2}: \lambda=0.303 ; \mathrm{t}=4.664\right)$. In fact, a greater weight is observed for dynamic capabilities, which is to be expected since market orientation, like strategic orientation, will tend to have a greater influence on strategic capabilities generated by the branch, as is the case of dynamic capabilities. This criterion, although in the opposite direction, also explains the results for the influence these two capabilities have on branch performance. Thus, in this case the effect on performance is directly determined by marketing capabilities, namely, the capabilities that allow specific actions to be operationalised and implemented in the market $\left(\mathrm{H}_{4}: \lambda=0.472 ; \mathrm{t}=2.566\right)$. The dynamic capabilities have no direct repercussion on branches' short-term performance $\left(\mathrm{H}_{3}: \lambda=0.062 ; \mathrm{t}=0.315\right)$, but have an indirect impact through their positive effect in maintaining the substantive nature of marketing capabilities $\left(\mathrm{H}_{5}: \lambda=0.717 ; \mathrm{t}=7.014\right)$.

Place Table 4 about here

\section{DISCUSSION AND CONCLUSIONS}

The main objective of this study was to propose and analyse a holistic model from the marketing approach, in which by drawing on ambidexterity theory, we integrated market orientation theory and the main efficiency-based models. With this model we empirically analysed the role of market orientation in bank branches as a strategic orientation associated with managing market intelligence to 
simultaneously develop two types of complimentary capabilities essential to sustainable branch performance: dynamic capabilities (related to knowledge exploration) and marketing capabilities (related to knowledge exploitation).

Through this general objective and in this context of innovative analysis, we aimed to respond to recent calls in the literature for new contributions from both theoretical and managerial perspectives.

\section{Theoretical implications}

Ambidexterity theory was the integrating theoretical frame for the proposed model. Our combined analysis of certain assumptions, recently studied separately in the literature, makes some significant contributions to the current knowledge and improves understanding of the application of ambidexterity theory at the core of the firm. Indeed, as Judge and Blocker (2008) note, despite recent growing interest in the study of ambidexterity in the business world, important questions remain unresolved. Although ambidexterity is being formally and informally explored in the organisational theory, strategic management, and marketing literatures, no cross fertilisation of ideas is taking place. There is therefore a clear need to integrate these disparate literatures to encourage this cross fertilisation and provide a coherent holistic picture.

According to Judge and Blocker (2008) one of the main unresolved questions in this research stream concerns the lack of research, especially empirical studies, into the potential contextual factors that favour ambidexterity. In the same line, recent studies continue to call for new research to identify antecedent factors that guarantee a suitable contextual unit in which to apply the ambidextrous approach in the firm (Fiset and Dostaler 2013; Carter 2015; Lee and Rha 2016). The results of the present study empirically demonstrate that market orientation is an essential strategic orientation; it is an antecedent of optimal development of an ambidextrous approach in bank branches that enables them to improve performance through the contribution market orientation makes to generating certain organisational capabilities. These results allow us to test the theoretical assumptions defended in previous studies that highlight the importance of adopting mechanisms for optimal knowledge management to facilitate the development of firms' ambidextrous functions ( $\mathrm{Li}$ et al. 2008; Chang et al. 2011; Lee and Huang 2012; Torres et al. 2015). 
Our results show that developing a market orientation will facilitate the generation and dissemination of market information and will inspire contact personnel in the branch to offer their services in the best possible way (Lings and Greenley 2009). This shared internal orientation means that employees proactively gather information on their customers' present and future needs, and on the various factors that might influence their behaviour (Fang et al. 2014). Branches with a market orientation therefore achieve customer satisfaction more simply by aligning and maintaining the symmetry between the internal development of their mechanisms, routines and capabilities, and the external efforts made on behalf of customers based on the existing market conditions (Zhang and Duan 2010).

The second gap in ambidexterity research concerns the need to operationalise the functions of exploration and exploitation, normally defined theoretically, in the form of certain specific capabilities associated with firms' competitive reality in their pursuit of improved performance (Fang et al. 2014; Monferrer et al. 2015). To bridge this gap, the study draws on the most representative strategic explanatory models of company competitiveness in the literature, namely efficiency-based models, which include the resources and capabilities based view and the theory of dynamic capabilities (Teece et al. 1997; Newbert 2007; Wu 2010). We proposed and empirically tested the influence on the market orientation-organisational performance relationship of two capabilities that perfectly reflect the essence of this dual ambidextrous function, namely, marketing capabilities and dynamic capabilities. The third gap concerns the striking absence of empirical studies analysing the way these two aspects of capability - exploitation and exploration - influence performance through their separate characteristics (Judge and Blocker 2008; Ho et al. 2011; Carter 2015; Eltantawy 2016; Lee and Rha 2016). Jointly considering the assumptions defended in the two efficiency-based competitive models allows us to overcome the limitations in the traditional literature, which by analysing them separately adopts an incomplete conception of how each of the functions of ambidexterity contribute to bank branch performance. Thus, on the one hand, considering exploitative substantive marketing capabilities in isolation assumes that they are static capabilities that will always be capable of generating positive firm performance. On the other hand considering in isolation exploratory dynamic capabilities as a direct source of influence on firm performance (Chien and Tsai 2012; Tseng and Lee 
2014) goes completely against their definition, which is based on maintaining the firm's capability to continue generating positive results in the future.

Taken together, as our results confirm, in highly dynamic, competitive and changeable environments both types of capability (substantive and dynamic, exploitative and explorative) should be taken into account in studies aiming to analyse the influence of organisational capabilities on performance. Specifically, on the one hand our results support evidence from previous studies that marketing capabilities can be considered as one of the most significant approaches through which banks can achieve performance differentiation. Marketing capabilities allow banks to understand market needs, introduce new products, organise marketing activities and strategies that provide unique value to their customers; they help to create and maintain relationships with them, achieve greater efficiency and cost control and, thus, help them to outperform their competitors (Tsai and Shih 2004; Krasnikov and Jayachandran 2008; Nath et al. 2010; Chahal and Kaur 2014; Fang et al. 2014; Kamboj and Rahman 2015). On the other hand, our results confirm that strategic and exploratory dynamic capabilities allow branches to follow a strategic approach associated with skills to adapt, update and/or renew in order to remain abreast with the market conditions at any given moment. By fostering a continuous up-to-date strategic context in the branch, these skills associated with dynamic capabilities will help to ensure that the branch's marketing capabilities will continue to contribute positively to its competitiveness in the market (Teece 2007; Helfat et al. 2007; Jantunen et al. 2008; Lidija and Robert 2014; Jiang et al. 2015; Schweizer et al. 2015; Lee and Rha 2016).

Dynamic capabilities, therefore, cannot have a direct effect on short-term performance in bank branches because they are designed to produce long-term results (Teece 2007; Kouropalatis et al. 2012; Monferrer et al. 2015). In contrast, they contribute to performance indirectly through their positive effect on maintaining the competitive and substantive nature of branches' marketing capabilities. These results contribute to bridge a fourth gap, namely, that despite extensive debate in the literature on the simultaneousness of these two diverging functions (exploration/exploitation), no studies have yet analysed the possible interrelationship between them (Eltantawy 2016; Lee and Rha 2016). 
Our model verifies a set of sequential relationships based on three types of basic variables: strategic factors that contribute to managing market knowledge, organisational capabilities, and firm performance (Zhang and Duan 2010; Chien and Tsai 2012; Tseng and Lee 2014; Wu and Chen 2014; Jin et al. 2015). The study therefore coincides with the views of a growing number of researchers who are questioning whether the mere possession of market orientation can provide firms with superior performance (Theodosiou et al. 2012; Fang et al. 2014). In fact, if the firm's competitors are also market oriented, not only does a market orientation fail to provide a competitive advantage, but it also becomes a cost of doing business or a failure preventer (Kumar et al. 2011). In this vein, several authors indicate that strategic orientations do not automatically lead to better performance, but bring complementary organisational capabilities that reflect the specific activities firms undertake to implement the chosen strategic direction, which in turn affects performance (Hult et al. 2005; Zhou et al. 2005; Morgan et al. 2009; Theodosiou et al. 2012). There was therefore a need to enhance current knowledge on the transformation of elements of organisational culture linked to strategic orientations into relevant capabilities that deliver value to customers and strengthen performance (Theodosiou et al. 2012; Fang et al. 2014).

Finally, the analysis was framed in a context traditionally left out of the ambidexterity literature: (1) analysis of the theory from a marketing approach (Monferrer et al. 2015); (2) micro-level analysis, in this case bank branches (Davidsson 2004; Schlosser and McNaughton 2007); and (3) analysis in sectors not linked to radical and extreme dynamism (technology- and innovation-intensive manufacturing industries). This the case of the services sector in general, and the banking sector in particular (Judge and Blocker 2008; Raisch et al. 2009; Chang et al. 2011). On this point, the study shows that ambidexterity theory offers ideal theoretical support for branches carrying out this dual explanatory/exploitative function. In the present environment, banks need to be ambidextrous to secure long-term competitiveness; in other words they need to balance the time branches spend on efficiently performing activities that contribute to achieving their targets through effective exploitation of existing resources and positions, and the time used to go further, showing exploratory initiative in the proactive search for opportunities that guarantee continued improvement and adaptation (Ho et al. 
2011; Kouropalatis et al. 2012; Lee and Huang 2012; Fiset and Dostaler 2013; Carter 2015; Torres et al. 2015; Zacher and Rosing 2015; Eltantawy 2016; Lee and Rha 2016).

Our results also make several complementary theoretical and empirical contributions to the literature on the analysed constructs. First, the domain of study allowed us to examine the market orientation construct in a way that is of great interest to the academic community. Many authors have identified a lack of research focusing on the role of market orientation in the services sector (Lettice et al. 2014; Kazakov 2016; Hinson et al. 2017; Salehzadeh et al. 2017; Zebal 2018). In addition, the role of market orientation in a negative crisis context has attracted little research attention (Grewal and Tansuhaj 2001; Ottesen and Gronhaug 2004; Naidoo 2010; Lettice et al. 2014). Second, some authors have recently argued that the literature has had to highlight the views of top-level company directors in market orientation analysis (Lam et al. 2010). However, the view of lower-level managers must also be taken into account if performance is to improve, particularly in service organisations. Lower-level managers have direct contact with customers and are also responsible for effectively transmitting a market orientation culture to customer contact employees, so they will implement a market-oriented strategy and ensure customer satisfaction (Marinova et al. 2008; Cadwallader et al. 2010; Lam et al. 2010). Nonetheless, there is limited empirical evidence in the area of strategic orientations on the relationship between lower-level managers and the development of firm capabilities (Theodosiou et al. 2012). Our study takes this lack of evidence into account by exploring the bank branch context.

\section{Managerial Implications}

Several recommendations for management can be drawn from the study's findings, which provide theoretical and empirical support for the concern expressed by service sector managers, particularly in the banking sector, to identify key factors with which to successfully tackle the process of change resulting from an increasingly dynamic environment. As noted earlier in this paper, the present study was undertaken in close collaboration with senior marketing managers from several of Spain's largest banks; through this collaboration a specific problem was identified, defined, agreed and confirmed at first hand from the business perspective.

First, despite the notable reduction of contact personnel $(29,000$ bank branches were closed between 2008 and 2014 in the Eurozone, with a loss of more than 200,000 jobs), marketing managers need to 
consider what effects this new business environment might have on their performance. Our study confirms the continuing importance of physical branches as a source of firm performance. Related to this, emotional links (based on relationships established with customers) tend to arise from personal interaction between contact staff and customers. If these interactions are kept to a minimum, the firmcustomer bond will essentially be rational, and thus not easy to sustain.

The solution, therefore, does not lie in closing branches, which are the point of contact with the customer; rather, banks must acknowledge the manifest need to reconsider the way their customer service is conceived. One of the senior managers consulted commented that "for many years our sector has closed its eyes to the need for change, which we could see coming from a long way off'. Today's bank customers are very different from the traditional profile. They are, among other aspects, (1) experienced, not only as a result of their own experiences, but also those of others; (2) demanding: not only are they familiar with their own rights and the firm's responsibilities, but they require them to be satisfied with each service; (3) informed: they have access to large amounts of information from a wide range of different sources; (4) independent: they have no ties and are not afraid to question changes in pursuit of greater practicality and better conditions of service.

The arrival of this new type of customer calls for a refocused concept of the branch and its functions that incorporate new variables such as flexibility and adaptability from both a strategic and an operational perspective. Indeed, customers who continue to visit the branch do so precisely because they want personal service adapted to their more specific needs. One of the senior marketing managers interviewed noted that "we have had to break out of the straitjacket that completely restricted the branches' movements, since the reality is that each branch is an individual entity with very different characteristics". Each branch conducts its business in a particular context, which may be radically different to other branches (in terms of customer type, business turnover, environmental conditions, needs for specific products and services, etc.). Branches must therefore have the flexibility they need to apply general directives through a local lens in order to achieve their own particular objectives.

In fact, this transformation process will be seen most clearly in the short term, since the sector remains strongly committed to promoting these notions, and is currently about to embark on what is known within the sector as "the branch of the future". Here, as this study has shown, there must be a 
continuing commitment to develop an ambidextrous approach at branch level based on a market orientation that helps generate a contextual unit grounded on the efficient management of specific market knowledge in which each unit carries out its own particular activity. This orientation must be applied to generate a dual exploration/exploitation function through two types of key capabilities: (1) marketing capabilities as the factor on which to operationalise marketing actions designed to generate value and in consequence, customer outcomes; and (2) dynamic capabilities as a factor that will guarantee sustainable marketing capabilities by ensuring branches are flexible, innovative and adaptable.

\section{LIMITATIONS AND FUTURE RESEARCH}

This study is not without certain limitations that should be taken into account when appraising the above conclusions. These limitations also point to possible lines for future research.

First, the unit of analysis in this study is limited to a specific service sector, the Spanish bank sector, in a context of considerable turbulence. New studies could usefully make comparisons with other service sectors and might also test the relationships posited in other international and less turbulent contexts, which would favour the generalisation of our results.

Second, this study is based on branch managers' data. By implication, our study drew on responses from a single interviewee from each branch in the sample. This raises the question of whether one person can respond appropriately on behalf of all the branch staff (Hogarth and Mkridakis 1981; Barnes 1984). In the case of organisational units with a large number of employees and departments, studies such as Schlosser and McNaughton (2007) find that in the same unit, depending on their position or rank, employees may show attitudes that can differ to a greater or lesser extent from their managers' perceptions. However, the organisational units in our study had an average of between five and six employees. In such a context the literature considers the branch manager to be the most capable person to speak sincerely on behalf of the unit (Weerawardena 2003; Davidsson 2004), since he or she has the most comprehensive knowledge of its characteristics, strategies and results (Hambrick 1981), is familiar with all aspects related to its operations, influences strategy management, and plays a fundamental role in taking important decisions (Miller and Toulouse 1986). 
Third, the use of transversal data, as is the case here, may be seen as a limitation when drawing causal inferences. This is particularly important to understand the differences in the results that the influence of explorative (long-term influence) and exploitative (short-term influence) have on actual branch performance.

Considering the second and third of these limitations together, future studies could explore the effects on the performance variable posited in our research using longitudinal data, which could complement the short-term performance view with a long-term outlook, particularly in terms of furthering understanding of the effects of dynamic capabilities on performance. Similarly, there is a need for new qualitative studies at different levels that take into account the responses of agents from different levels of the bank hierarchy. A quantitative approach could be taken using SEM models to apply data in dyads to analyse the causal relationships between factors associated with agents at different levels in the hierarchy according to levels of responsibility (top managers, branch manager, branch employees). Such studies may be able to determine similarities at different hierarchical levels in perceptions of the strategic and operational factors associated with ambidexterity that are actually implemented at the branch level.

Finally, our model represents a specific contribution on the basis of which new effects can be proposed by considering new factors. Future research may also consider the influence of other antecedents, other types of capabilities and other result variables. In this vein, and linked to the proposal for research using dyads, the relationships proposed here could be complemented with analysis of firm-customer dyads (Moliner et al. 2018). This approach could usefully examine how the practices analysed in this study from the branch manager's perspective would affect relational conduct and behaviours of branch customers through constructs such as customer engagement, advocacy, satisfaction, trust or loyalty. Such an approach would offer a broader view of the performance construct determined by the dual firm-customer viewpoint, and also take into account both transactional and non-transactional results. 


\section{REFERENCES}

Akman G, Yilmaz C. (2008), “Innovative capability, innovation strategy and market orientation”, International Journal of Innovation Management, 12(1): 69-111.

Al Mamun A, Mohiuddin M, Fazal SA, Ahmad GB. (2018), "Effect of entrepreneurial and market orientation on consumer engagement and performance of manufacturing SMEs”, Management Research Review, 41(1): 133-147.

Armstrong JS, Overton, TS. (1977), "Estimating non-response bias in mail surveys", Journal of Marketing Research, 16: 396-402.

Atuahene-Gima K. (2005), "Resolving the capability-rigidity paradox in new product innovation”, Journal of Marketing, 69(4): 61-83.

Atuahene-Gima K., Murray JY. (2007), "Exploratory and Exploitative learning in new product development: a social capital perspective on new technology ventures in China", Journal of International Marketing, 15(2): 1-29.

Baird K, Hu KJ, Reeve R. (2011), “The relationships between organizational culture, total quality management practices and operational performance", International Journal of Operations \& Production Management, 31(7): 789-814

Barnes JH. (1984), "Cognitive biases and their impact on strategic planning”, Strategic Management Journal, 5(April/June): 129-38.

Benner MJ, Tushman M. (2003), "Exploitation, exploration, and process management: the productivity dilemma revisited", Academy of Management Review, 28(2): 238-56.

Berger CR. (1979), "Beyond initial interaction: uncertainty, understanding, and the development of interpersonal relationships". In Language and Social Psychology, Giles H, Clair RN (eds). University Park, Baltimore, MD: 122-44.

Cadwallader S., Jarvis CB, Bitner MJ, Ostrom AL. (2010), "Frontline employee motivation to participate in service innovation implementation”, Journal of the Academy of Marketing Science, 38(2): 219-239.

Carter WR. (2015), “Ambidexterity deconstructed: a hierarchy of capabilities perspective”, Management Research Review, 38(8): 794-812.

Chahal H., Kaur J. (2014), "Development of marketing capabilities scale in banking sector”, Measuring Business Excellence, 18(4): 65-85. 
Chang YY, Hughes M, Hotho S. (2011), 'Internal and external antecedents of SMEs' innovation ambidexterity outcomes", Management Decision, 49(10): 1658-1676.

Chen YS, Lin MJJ, Chang CH. (2009), "The positive effects of relationship learning and absorptive capacity on innovation performance and competitive advantage in industrial markets", Industrial Marketing Management, 38: 152-158.

Chien SY, Tsai CH. (2012), "Dynamic capability, knowledge, learning, and firm performance", Journal of Organizational Change Management, 25(3): 434-444.

Churchill GA Jr. (1979), “A Paradigm for Developing Better Measures in Marketing”, Journal of Marketing Research, 16: 64-73.

Clercq DD, Dimov D, Thongpapanl NT. (2010), “The moderating impact of internal social exchange processes on the entrepreneurial orientation-performance relationship", Journal of Business Venturing, 25(1): 87103.

Davidsson P. (2004), "Researching on Entrepreneurship”, Springer, New York, USA.

Dawes J. (1999), “The relationship between subjective and objective company performance measures in market orientation research: further empirical evidence", Marketing Bulletin, 10(1): 65-76.

Day GS. (1994), “The capabilities of market-driven organizations”, Journal of Marketing, 58(4): 37-52.

Deighton J, Rizley R, Keane S. (2012), "Research priorities of the Marketing Science Institute: 2012-2014”, Marketing Science, 31(6): 873-877.

Dess GG, Robinson JRB. (1984), "Measuring organizational performance in the absence of objective measures: the case of the privately-held firm and conglomerate business unit", Strategic Management Journal, 5(3): 265-273.

Duncan RB. (1976), “The ambidextrous organization: designing dual structures for innovation". In The Management of Organizational Design, Kilman R, Pondy L (eds). North Holland, New York, NY: 16788.

Eisenhardt KM, Martin J. (2000), "Dynamic capabilities: what are they?", Strategic Management Journal, 21(10/11): 1105-1121

Ellis PD. (2006), "Market orientation and performance: a meta-analysis and cross-national comparisons", Journal of Management Studies, 43(5): 1089-1107.

Eltantawy RA. (2016), “The role of supply management resilience in attaining ambidexterity: a dynamic capabilities approach", Journal of Business \& Industrial Marketing, 31(1): 123-134. 
Fang SR, Chang E, Ou CC, Chou CH. (2014), “Internal market orientation, market capabilities and learning orientation”, European Journal of Marketing, 48(1/2): 170-192.

Fiset J, Dostaler I. (2013), “Combining old and new tricks: ambidexterity in aerospace design and integration teams", Team Performance Management, 19(7/8): 314-330.

Fornell C, Larcker DF. (1981), "Evaluating structural equation models with unobservable variables and measurement error", Journal of Marketing Research, 18: 39-50.

Friedrich TL, Byrne CL, Mumford MD. (2009), "Methodological and theoretical considerations in survey research", The Leadership Quarterly, 20: 57-60.

Gibson CB, Birkinshaw J. (2004), "The antecedents, consequences and mediating role of organizational ambidexterity”, Academy of Management Journal, 47: 209-226.

Gijsenberg MJ, Van Heerde HJ, Verhoef PC. (2015), "Losses loom longer than gains: modeling the impact of service crises on perceived service quality over time", Journal of Marketing Research, 52(5): 642-656.

Grant RM. (1996), "Prospering in dynamically-competitive environments: Organizational capability as knowledge integration", Organization Science, 7(4): 375-387.

Grewal R, Tansuhaj P. (2001), "Building organizational capabilities for managing economic crisis: The role of market orientation and strategic flexibility", Journal of Marketing, 65: 67-80.

Grinstein A. (2008), “The relationships between market orientation and alternative strategic orientations: A meta-analysis", European Journal of Marketing, 42(1/2): 115-134.

Guenzi P, Troilo G. (2006), "Developing marketing capabilities for customer value creation through marketingsales integration”, Industrial Marketing Management, 35(11): 974-988.

Ha-Brookshire JA, Dyer B. (2009), "The impact of firm capabilities and competitive advantages on import intermediary performance", Journal of Global Marketing, 22(1): 5-19.

Hair JF, Black WC, Babin BJ and Anderson, RE. (2009), “Multivariate data analysis”, Prentice Hall, Upper Saddle River, NJ.

Hambrick DC. (1981), "Strategic awareness within top management teams”, Strategic Management Journal, 2 : 263-79.

Hansen T. (2014), “The role of trust in financial customer-seller relationships before and after the financial crisis", Journal of Consumer Behaviour, 13: 442-452.

Harman HH. (1976), “Modern factor analysis” (3rd ed.) Chicago: The University of Chicago Press. 
Helfat CE, Finkelstein S, Mitchell W, Peteraf MA, Singh H, Teece DJ, Winter SG. (2007), "Dynamic capabilities: understanding strategic change and organizations". Blackwell, London.

Hinson RE, Abdul-Hamid IK, Osabutey ELC. (2017), "Investigating market orientation and positioning in starrated hotels in Ghana"”, International Journal of Contemporary Hospitality Management, 29(10): 2629-2646.

Ho YC, Fang HC, Lin JF. (2011), “Technological and design capabilities: is ambidexterity possible?", Management Decision, 49(2): 208-225.

Hofer CW. (1975), "Towards a contingency theory of business strategy", Academy of Management Journal, 18(4): 784-810.

Hogarth R, Mkridakis S. (1981), “Forecasting and planning: an evaluation”, Journal of Marketing, 49(Fall): 1112.

Hooley GJ, Greenley GE, Cadogan JW, Fahy J. (2005), “The performance impact of marketing resources”, Journal of Business Research, 58: 18-27.

Hou JJ. (2008), “Toward a research model of market orientation and dynamic capabilities", Social Behavior and Personality, 36(9): 1251-1268.

Hult TG, Ketchen DJ. (2001), "Does market orientation matter? A test of the relationship between positional advantage and performance", Strategic Management Journal, 22: 899-906.

Hult TG, Ketchen DJ, Slater SF. (2005), "Market orientation and performance: An integration of disparate approaches”, Strategic Management Journal, 26(12): 1173-1181.

Jansen JJ, George G, Van den Bosch FA, Volberda HW. (2009), “Senior team attributes and organizational ambidexterity: the moderating role of transformational leadership", Journal of Management Studies, 45(5): 982-1007.

Jansen J, Van den Bosch F., Volberda H. (2005), "Exploratory innovation, exploitive innovation, and ambidexterity: the impact of environmental and organizational antecedents", Schmalenbach Business Review, 57: 351-63.

Jansen J, Van Den Bosch F, Volberda H. (2006), "Exploratory innovation, exploitative innovation, and performance: effects of organizational antecedents and environmental moderators", Management Science, 52(11): 1661-74.

Jantunen A, Nummela N, Puumalinen K, Saarenketo S. (2008), "Strategic orientation of born globals - do they really matter?", Journal of World Business, 43(2): 158-70. 
Jarvis R., Curran J, Kitching J, Lightfoot G. (2000), “The use of quantitative and qualitative criteria in the measurement of performance in small firms", Journal of Small Business and Enterprise Development, 7(2): $123-134$.

Jaworski B, Kohli A, Sahay A. (2000), "Market-driven versus driving markets", Journal of Academy of Marketing Science, 28(1): 45-54.

Jiang W, Mavondo FT, Matanda MJ. (2015), “Integrative capability for successful partnering: a critical dynamic capability”, Management Decision, 53(6): 1184-1202.

Jin X, Wang J, Chen S, Wang T. (2015), “A study of the relationship between the knowledge base and the innovation performance under the organizational slack regulating”, Management Decision, 53(10): $2202-2225$.

Johnson DS, Peterson M. (2014), “Consumer financial anxiety”, International Journal of Bank Marketing, 32(6): 515-533.

Jöreskog K, Söbom D. (1993), "LISREL 8: structural equation modeling with the SIMPLIS command language”. Scientific Software International, Chicago, Illinois.

Judge WQ, Blocker CP. (2008), “Organizational capacity for change and strategic ambidexterity”, European Journal of Marketing, 42(9/10): 915-926.

Kamboj S, Rahman Z. (2015), "Marketing capabilities and firm performance: literature review and future research agenda”, International Journal of Productivity and Performance Management, 64(8): 10411067.

Kaytaz M., Gul MC. (2014), “Consumer response to economic crisis and lessons for marketers: The Turkish experience", Journal of Business Research, 67(1): 2701-2706.

Kazakov S. (2016), “The impact of market orientation levels on business performance results: The case of the service industry in Russia”, Worldwide Hospitality and Tourism Themes, 8(3): 296-309.

Kouropalatis Y, Hughes P, Morgan RE. (2012), "Pursuing “flexible commitment” as strategic ambidexterity", European Journal of Marketing, 46(10): 1389-1417.

Kohli AK, Jaworski BJ. (1990), "Market orientation: The construct, research propositions and managerial implications", Journal of Marketing, 54(2): 1-18.

Kolar T. (2006), "Benchmarking market orientation of banks in transitional markets: Exploring a modified approach”, International Journal of Bank Marketing, 24(2): 76-97. 
Krasnikov A, Jayachandran S. (2008), "The relative impact of marketing, research and development, and operations capabilities on firm performance”, Journal of Marketing, 72(4): 1-11.

Kraus S, Rigtering JC, Hughes M, Hosman V. (2012), "Entrepreneurial orientation and the business performance of SMEs: a quantitative study from the Netherlands", Review of Managerial Science, 6(2): 161-182.

Kumar V, Jones E, Venkatesan R, Leone RP. (2011), "Is market orientation a source of sustainable competitive advantage or simply the cost of competing?", Journal of Marketing, 75: 16-30.

Kwon YC. (2010), "Market orientation of Korean MNC subsidiaries and their performance in the Chinese and Indian markets", International Marketing Review, 27(2): 179-199.

Lam SK, Kraus F, Ahearne M. (2010), "The diffusion of market orientation throughout the organization: A social learning theory perspective", Journal of Marketing, 74: 61-79.

Lee CY, Huang YC. (2012), "Knowledge stock, ambidextrous learning, and firm performance", Management Decision, 50(6): 1096-1116.

Lee SM, Rha JS. (2016), “Ambidextrous supply chain as a dynamic capability: building a resilient supply chain", Management Decision, 54(1): 2-23.

Lettice F, Tschida M, Forstenlechner I. (2014), "Managing in an economic crisis: The role of market orientation in an international law firm", Journal of Business Research, 67(1): 2693-2700.

Li CR, Lin CJ, Chu CP. (2008), "The nature of market orientation and the ambidexterity of innovations", Management Decision, 46(7): 1002-1026.

Liao SH, Chang WJ, Wu CC, Katrichis JM. (2011), “A survey of market orientation research (1995-2008)”, Industrial Marketing Management, 40: 301-310.

Lidija B, Robert DH. (2014), “Dynamic capabilities vs. innovation capability: are they related?”, Journal of Small Business and Enterprise Development, 21(3): 368-384.

Lings I, Greenley G. (2009), “The impact of internal and external market orientations on firm performance”, Journal of Strategic Marketing, 17(1): 41-53.

Liu G, Ko WWJ, Ngugi I, Takeda S. (2017), "Proactive entrepreneurial behaviour, market orientation, and innovation outcomes: A study of small- and medium-sized manufacturing firms in the UK", European Journal of Marketing, 51(11/12): 1980-2001.

Makkonen H, Pohjola M, Olkkonen R, Koponen A. (2014), “Dynamic capabilities and firm performance in a financial crisis", Journal of Business Research, 67(1): 2707-2719. 
Manan DIA, Jan NM. (2010), “Do Resources Contribute to Firms' Performances? Exploring Batik Industry in Malaysia”, International Review of Business Research Papers, 6(3): 189-204.

March JG. (1991), "Exploration and exploitation in organizational learning”, Organization Science, 2: 71-87.

March JG, Sutton RI. (1997), “Organizational performance as a dependent variable”, Organizational Science, 8(6): 698-706.

March JG. (2006), "Rationality, foolishness, and adaptive intelligence”, Strategic Management Journal, 27(3): 201-214.

Marinova D, Ye J, Singh J. (2008), "Do frontline mechanisms matter? Impact of quality and productivity orientations on unit revenue, efficiency, and customer satisfaction”, Journal of Marketing, 72(2): 28-45.

Martí F, Pérez J. (2015), “Spanish public finances through the financial crisis”, Fiscal Studies, 36(4): 527-554.

McCarthy IP, Gordon BR. (2011), “Achieving contextual ambidexterity in R\&D organizations: a management control system approach", R\&D Management, 41(3): 240-258.

McGrath RG. (2001), "Exploratory learning, innovative capacity, and managerial oversight", Academy of Management Journal, 44(1): 118-131.

Miller D, Toulouse JM. (1986), "Chief executive personality and corporate strategy and structure in small firms", Management Science, 32(1): 1389-409.

Moliner MA, Monferrer D, Estrada M. (2018), "Consequences of customer engagement and customer selfbrand connection", Journal of Services Marketing, https://doi.org/10.1108/JSM-08-2016-0320.

Monferrer D. (2011), "La orientación al mercado de la red como determinante de la competitividad de las nuevas empresas internacionales. El efecto mediador de las capacidades dinámicas”. Doctoral dissertation. Universitat Jaume I, Spain.

Monferrer D, Blesa A, Ripollés M. (2015), "Born globals trough knowledge-based dynamic capabilities and network market orientation”, Business Research Quarterly, 18(1): 18-36.

Monferrer D, Estrada M, Fandos JC, Moliner MA, Sánchez J. (2016), "Service quality in bank during an economic crisis”, International Journal of Bank Marketing, 34(2): 235-259.

Morgan NA, Vorhies DW, Mason CH. (2009), "Market orientation, marketing capabilities and firm performance”, Strategic Management Journal, 30(8): 909-920.

Murray JY, Gao GY, Kotabe M. (2011), "Market orientation and performance of export ventures: The process through marketing capabilities and competitive advantages", Journal of the Academy of Marketing Science, 39(2): 252-269. 
Naidoo V. (2010), "Firm survival through a crisis: The influence of market orientation, marketing innovation and business strategy", Industrial Marketing Management, 39(8): 1311-1320.

Naman, JL, Slevin DP. (1993), "Entrepreneurship and the concept of fit: a model and empirical tests", Strategic Management Journal, 14(2): 137-153.

Narver JC, Slater SF. (1990), "The effect of a market orientation on business profitability", Journal of Marketing, 54: 20-35.

Narver JC, Slater SF, MacLachlan DL. (2004), "Responsive and proactive market orientation and new-product success", Journal of Product Innovation Management, 21(5): 334-47.

Nath P, Nachiappan S, Ramanathan R. (2010), "The impact of marketing capability, operations capability and diversification strategy on performance: a resource-based view", Industrial Marketing Management, 39(2): 317-329.

Nelson RR, Winter SG. (1982), “An Evolutionary Theory of Economic Change”. Harvard University Press, Cambridge, MA.

Newbert SL. (2007), "Empirical research on the resource based view of the firm: an assessment and suggestions for future research", Strategic Management Journal, 28(2): 121-146.

Nunnally J. (1979), “Psychometric Theory”. McGraw-Hill, Nueva York.

O’Reilly CA, Tushman M. (2004), “The ambidextrous organization”, Harvard Business Review, 82(4): 74-82.

Ottesen GG, Grønhaug K. (2004), "Exploring the dynamics of market orientation in turbulent environments: A case study", European Journal of Marketing, 38(8): 956-973.

Pearce JA, Robbins DK, Robinson RB. (1987), "The impact of grand strategy and planning formality on financial performance", Strategic Management Journal, 8(2): 125-134.

Penrose E. (1959), “The Theory of the Growth of the Firm”. Blackwell, London.

Podsakoff PM, MacKenzie SB, Lee J, Podsakoff N. (2003), "Common method biases in behavioral research: A critical review of the literature and recommended remedies", Journal of Applied Psychology, 88: 879903.

Raisch S, Birkinshaw J, Probst G, Tushman ML. (2009), “Organizational ambidexterity: balancing exploitation and exploration for sustained performance”, Organization Science, 20(4): 685-695.

Ray G, Barney JB, Muhanna WA. (2004), “Capabilities, business processes, and competitive advantage: choosing the dependent variable in empirical tests of the resource-based view", Strategic Management Journal, 25: 23-37. 
Richard PJ, Devinney TM, Yip GS, Johnson G. (2009), "Measuring organizational performance: towards methodological best practice", Journal of Management, 35(5): 718-804.

Ruiz B, Esteban A, Gutiérrez S. (2014), "Determinants of reputation of leading Spanish financial institutions among their customers in a context of economic crisis”, Business Research Quarterly, 17(4): 259-278.

Rumelt RP. (1984), “Toward a Strategic Theory of the Firm”. In Competitive Strategic Management, Lamb R. (eds). Prentice-Hall, Englewood Cliffs, NJ: 556-570.

Salehzadeh R, Pool JK, Tabaeeian RA, Amani M, Mortazavi. (2017), “The impact of internal marketing and market orientation on performance: an empirical study in restaurant industry", Measuring Business Excellence, 21(4): 273-290.

Santos JB, Brito LAL. (2012), “Toward a subjective measurement model for firm performance”, BAR-Brazilian Administration Review, 9(6): 95-117.

Schlosser F, McNaughton R. (2007), “Internal stakeholder views of a market orientation strategy: implications for implementation", Journal of Strategic Marketing, 15(4): 307-325.

Schweizer L, Rogbeer S, Michaelis, B. (2015), "The dynamic capabilities perspective: from fragments to metatheory", Management Research Review, 38(7): 662-684.

Shoham A. (1998), "Export performance: a conceptualisation and empirical assessment", Journal of International Marketing, 6(3): 59-81.

Shoham A, Rose GM, Kropp F. (2005), "Market orientation and performance: a meta-analysis", Marketing Intelligence \& Planning, 23(5): 435-454.

Silvestro R. (2014), “Performance topology mapping: understanding the drivers of performance”, International Journal of Production Economics, 156(1): 269-282.

Song M, Droge C, Hanvanich S, Calantone R. (2005), "Marketing and technology resource complementarity: an analysis of their interaction effect in two environmental contexts", Strategic Management Journal 26(3): 259-276.

Steenkamp JBEM, van Trijp HCM. (1991), "The use of LISREL in validating marketing constructs", International Journal of Reesearch in Marketing, 8(4): 283-299.

Styles C. (1998), "Export performance measures in Australia and the United Kigdom”, Journal of International Marketing, 6(3): 12-36.

Teece DJ. (1984), "Economic analysis and strategic management", California Management Review, 26(3): 87110. 
Teece D. (2007), "Explicating dynamic capabilities: the nature and microfundations of (sustainable) enterprise performance”, Strategic Management Journal, 28(13): 1319-1350.

Teece D, Pisano G, Shuen A. (1997), “Dynamics capabilities and strategic management”, Strategic Management Journal, 18(7): 509-533.

Theodosiou M, Kehagias J, Katsikea E. (2012), "Strategic orientations, marketing capabilities and firm performance: An empirical investigation in the context of frontline managers in service organizations", Industrial Marketing Management, 41(7): 1058-1070.

Torres JP, Drago C, Aqueveque C. (2015), “Knowledge inflows effects on middle managers' ambidexterity and performance", Management Decision, 53(10): 2303-2320.

Tsai MT, Shih CM. (2004), “The impact of marketing knowledge among managers on marketing capabilities and business performance", International Journal of Management, 21(4): 524-530.

Tseng SM, Lee PS. (2014), "The effect of knowledge management capability and dynamic capability on organizational performance”, Journal of Enterprise Information Management, 27(2): 158-179.

Tushman M, O’Reilly CA. (1996), "Evolution and revolution: mastering the dynamics of innovation and change", California Management Review, 38(4): 8-30.

Venkatraman N, Ramanujam V. (1987), "Measurement of business economic performance: an examination of method convergence", Journal of Management, 13(1): 109-122.

Venkatraman N. (1989), “The concept of fit in strategy research: Toward verbal and statistical correspondence”, Academy of Management Review, 14(3): 423-444.

Vij S, Bedi HS. (2016) “Are subjective business performance measures justified?” International Journal of Productivity and Performance Management, 65(5): 603-621.

Vorhies DW, Harker M, Rao CP. (1999), “The capabilities and performance advantages of market-driven firms”, European Journal of Marketing, 33(11/12): 1171-1202.

Vorhies DW, Morgan NA. (2005), "Benchmarking marketing capabilities for sustainable competitive advantage”, Journal of Marketing, 69: 80-94.

Vorhies DW, Morgan RE, Autry CW. (2009), "Product-market strategy and the marketing capabilities of the firm: Impact on market effectiveness and cash flow performance", Strategic Management Journal, 30(12): 1310-1334.

Wall TD, Michie J, Patterson M, Wood SJ, Sheehan M, Clegg CW, West M. (2004), "On the validity of subjective measures of company performance”, Personnel Psychology, 57(1): 95-118. 
Wang CL, Ahmed PK. (2007), "Dynamic capabilities: a review and research agenda", International Journal of Management Reviews, 9(1): 31-51.

Wang ETG, Lin CCL, Jiangb JJ, Klein G. (2007), "Improving enterprise resource planning (ERP) fit to organizational process through knowledge transfer", International Journal of Information Management, 27(3): 200-212.

Weerawardena J, (2003) "Exploring the role of market learning capability in competitive strategy", European Journal of Marketing, 37(3/4): 407-429.

Wernerfelt B. (1984), “A resource-based view of the firm”, Strategic Management Journal, 5: 171-180.

Wiklund J, Shepherd D. (2005), “Entrepreneurial orientation and small business performance: a configurational approach”, Journal of Business Venturing, 20(1): 71-89.

Wood EH. (2006), "The internal predictors of business performance in small firms”, Journal of Small Business and Enterprise Development, 13(3), 441-452.

Wu LY. (2010), “Applicability of the resource-based and dynamic-capability views under environmental volatility”, Journal of Business Research, 63: 27-31.

Wu IL, Chen JL. (2014), "Knowledge management driven firm performance: the roles of business process capabilities and organizational learning”, Journal of Knowledge Management, 18(6): 1141-1164.

Zacher H, Rosing K. (2015), “Ambidextrous leadership and team innovation”, Leadership \& Organization Development Journal 36(1): 54-68.

Zahra SA. (1999), "The changing rules of global competitiveness in the 21st century”, Academy of Management Executive, 13(1): 36-42.

Zahra SA, George G. (2002), “Absorptive capacity: a review, reconceptualization and extension”, Academy of Management Review, 27(2): 213-240.

Zahra SA, Sapienza H, Davidsson P. (2006), "Entrepreneurship and dynamic capabilities: a review, model and research agenda", Journal of Management Studies, 43(4): 917-955.

Zebal MA. (2018), The impact of internal and external market orientation on the performance of nonconventional Islamic financial institutions”, Journal of Islamic Marketing, 9(1): 132-151.

Zhang J, Duan Y. (2010), “The impact of different types of market orientation on product innovation performance", Management Decision, 48(6): 849-867.

Zhou KZ, Li CB. (2010), "How strategic orientations influence the building of dynamic capability in emerging economies", Journal of Business Research, 63(3): 224-231. 
Zhou KZ, Li JJ, Zhou N, Su C. (2008), "Market orientation, job satisfaction, product quality and firm performance: Evidence from China”, Strategic Management Journal, 29: 985-1000.

Zhou KZ, Yim CK, Tse DK. (2005), “The effects of strategic orientations on technology-and market-based breakthrough innovations", Journal of Marketing, 69(2): 42-60.

Zollo M, Winter S. (2002), "Deliberate learning and the evolution of dynamic capabilities"; Organization Science, 13(3): 339-351. 
Table 1: Scales used

\begin{tabular}{llccc}
\hline \multicolumn{1}{c}{ Variables } & \multicolumn{1}{c}{ References } & Dimensions & Items & Scale \\
\hline Market orientation & Kolar (2006) & 4 & $15(3 ; 4 ; 4 ; 4)$ & 5-point Likert \\
& $\begin{array}{l}\text { Gibson and Brikinshaw (2004); } \\
\text { Chen et al (2009); Akman and } \\
\text { Dynamic capabilities }\end{array}$ & 3 & 11 $(3 ; 3 ; 5)$ & 5-point Likert \\
& $\begin{array}{l}\text { Yilmaz (2008) } \\
\text { Vorhies and Morgan (2005) }\end{array}$ & 4 & 16 (3;3;4;6) & 5-point Likert \\
Marketing capabilities & Jantunen et al. 2008 & 1 & 4 & 5-point Likert \\
Performance &
\end{tabular}


Table 2: Summary of the results after factor, reliability and validity analysis

\begin{tabular}{|c|c|c|}
\hline Items & $\begin{array}{l}\text { Factor } \\
\text { loading }\end{array}$ & t-value \\
\hline \multicolumn{3}{|l|}{ MARKET ORIENTATION $(\mathrm{CR}=0.96 ; \mathrm{AVE}=0.86)$} \\
\hline Intelligence generation $(\alpha=0.740 ; \mathrm{CR}=0.72 ; \mathrm{AVE}=0.56)$ & 0.967 & $11.821 *$ \\
\hline GEN1: We regularly analyse the factors that influence customer satisfaction. & 0.741 & Fixed \\
\hline $\begin{array}{l}\text { GEN2: We regularly analyse the improvement in our employees' satisfaction and compare it } \\
\text { with their performance. }\end{array}$ & \multicolumn{2}{|c|}{ Deleted } \\
\hline $\begin{array}{l}\text { GEN3: It is just as important for us to achieve marketing objectives (customer satisfaction and } \\
\text { loyalty, service quality) as it is to meet our financial targets. }\end{array}$ & 0.755 & $9.859 *$ \\
\hline Intelligence dissemination $(\alpha=0.829 ; \mathrm{CR}=0.79 ; \mathrm{AVE}=0.50)$ & 0.950 & $14.402 *$ \\
\hline $\begin{array}{l}\text { DIS1: Our firm's mission is reflected and implemented in our plans and interventions addressing } \\
\text { customer satisfaction. }\end{array}$ & 0.733 & Fixed \\
\hline DIS2: Customer satisfaction and quality improvement are regularly dealt with in our meetings. & 0.697 & $11.629 *$ \\
\hline DIS3: Our targets include specific customer satisfaction and quality improvement objectives. & 0.715 & $12.312 *$ \\
\hline $\begin{array}{l}\text { DIS4: We inform about possible future changes in an integrated, logical and objective way, } \\
\text { including any possible disadvantages associated with the change, and by exploring our } \\
\text { employees' opinions. }\end{array}$ & 0.652 & $10.998 *$ \\
\hline Responsiveness $(\alpha=0.762 ; \mathrm{CR}=0.75 ; \mathrm{AVE}=0.50)$ & 0.930 & $12.312 *$ \\
\hline $\begin{array}{l}\text { RES1: We demonstrate our interest in building a closer relationship with customers through a } \\
\text { range of actions (such as responding personally to their questions). }\end{array}$ & 0.751 & Fixed \\
\hline $\begin{array}{l}\text { RES2: We have a structured system for the continued improvement of customer satisfaction and } \\
\text { service quality (surveys, customer complaint and relations management, etc.). }\end{array}$ & 0.640 & $10.422 *$ \\
\hline RES3: We are ready to face new challenges and learn new skills. & \multicolumn{2}{|c|}{ Deleted } \\
\hline RES4: We analyse our main functions to optimise them and minimise their failure rate. & 0.716 & $11.003 *$ \\
\hline Marketing culture $(\alpha=0.837 ; \mathrm{CR}=0.81 ; \mathrm{AVE}=0.52)$ & 0.866 & $12.517 *$ \\
\hline $\begin{array}{l}\text { CUL1: We reward our branch personnel for their contributions to customer satisfaction and for } \\
\text { improving service quality. }\end{array}$ & 0.714 & Fixed \\
\hline CUL2: We have sufficient authority and information to take decisions flexibly. & 0.728 & $11.822 *$ \\
\hline $\begin{array}{l}\text { CUL3: We have the capability to implement innovations without the need for numerous rounds } \\
\text { of approval at different levels in the hierarchy. }\end{array}$ & 0.677 & $10.012 *$ \\
\hline $\begin{array}{l}\text { CUL4: The flexible interpretation of the work procedures, norms and policies are not regarded } \\
\text { as a problem in our branch. }\end{array}$ & 0.752 & $9.774 *$ \\
\hline \multicolumn{3}{|l|}{ DYNAMIC CAPABILITIES $(\mathrm{CR}=0.89 ; \mathrm{AVE}=0.73)$} \\
\hline Adaptation capabilities $(\alpha=0.808 ; \mathrm{CR}=0.83 ; \mathrm{AVE}=0.62)$ & 0.825 & $12.548^{*}$ \\
\hline $\begin{array}{l}\text { ADA1: Our employees are capable of adapting to each situation and using different alternatives } \\
\text { when doing their work. }\end{array}$ & 0.740 & Fixed \\
\hline $\begin{array}{l}\text { ADA2: In our branch we are sufficiently flexible to respond quickly to market changes and } \\
\text { opportunities. }\end{array}$ & 0.814 & $11.554 *$ \\
\hline $\begin{array}{l}\text { ADA3: We are capable of rapidly adopting changes in strategy in accordance with our business } \\
\text { priorities. }\end{array}$ & 0.802 & $11.449 *$ \\
\hline Absorption capability $(\alpha=0.873 ; \mathrm{CR}=0.87 ; \mathrm{AVE}=0.70)$ & 0.834 & $14.007 *$ \\
\hline $\begin{array}{l}\text { ABS1: In this branch we are capable of commercially applying the information we gather from } \\
\text { our environment/market. }\end{array}$ & 0.762 & Fixed \\
\hline $\begin{array}{l}\text { ABS2: We are capable of understanding, analysing and interpreting the information from our } \\
\text { environment/market. }\end{array}$ & 0.862 & $17.388^{*}$ \\
\hline $\begin{array}{l}\text { ABS3: We are capable of combining and assimilating this new external information with our } \\
\text { existing internal knowledge. }\end{array}$ & 0.880 & $17.803^{*}$ \\
\hline Innovation capability $(\alpha=0.874 ; \mathrm{CR}=0.87 ; \mathrm{AVE}=0.58)$ & 0.903 & $14.062 *$ \\
\hline INN1: In our branch we are receptive to creativity and innov & 0.708 & Fixed \\
\hline $\begin{array}{l}\text { INN2: We are capable of using different sources of information to contribute innovative and } \\
\text { effective solutions quickly. }\end{array}$ & 0.811 & $15.005^{*}$ \\
\hline $\begin{array}{l}\text { INN3: The employees in our branch are capable of contributing in activities such as developing } \\
\text { new ideas, improving the customer attention process, improving products/services. }\end{array}$ & 0.758 & $14.085^{*}$ \\
\hline $\begin{array}{l}\text { INN4: We are capable of evaluating ideas from other agents (customers, organisations, suppliers, } \\
\text { etc.) for consideration when conducting our activity. }\end{array}$ & 0.780 & $14.403 *$ \\
\hline $\begin{array}{l}\text { INN5: Our branch promptly keeps abreast with changes in the environment and incorporates } \\
\text { pertinent improvements and innovation. }\end{array}$ & 0.745 & $13.852 *$ \\
\hline \multicolumn{3}{|l|}{ MARKETING CAPABILITIES (CR=0.89; AVE=0.68) } \\
\hline Pricing capability $(\alpha=0.768 ; \mathrm{CR}=0.82 ; \mathrm{AVE}=0.69)$ & 0.638 & $10.027 *$ \\
\hline PRI1: We monitor competitors' prices and any possible changes. & 0.783 & Fixed \\
\hline PRI2: We set the prices of our products and services in an effective way. & \multicolumn{2}{|c|}{ Deleted } \\
\hline $\begin{array}{l}\text { PRI3: In the branch we are able to offer different conditions and prices depending on the } \\
\text { variations in our market. }\end{array}$ & 0.875 & $12.285^{*}$ \\
\hline Commercialisation of product capability $(\alpha=0.773 ; \mathrm{CR}=0.78 ; \mathrm{AVE}=0.54)$ & 0.823 & $11.934 *$ \\
\hline
\end{tabular}




\begin{tabular}{|c|c|c|}
\hline PRO1: New products/services are subjected to certain market trials. & 0.671 & Fixed \\
\hline $\begin{array}{l}\text { PRO2: In our branch we are skilful in successfully commercialising the new products/services we } \\
\text { introduce. }\end{array}$ & 0.749 & $12.231 *$ \\
\hline $\begin{array}{l}\text { PRO3: Our branch helps to develop innovations that allow responses to be provided to our } \\
\text { customers' needs. }\end{array}$ & 0.783 & $12.512 *$ \\
\hline Channel management capability $(\alpha=0.814 ; \mathrm{CR}=0.80 ; \mathrm{AVE}=0.50)$ & 0.898 & $12.106^{*}$ \\
\hline CHA1: We try to add additional value to the business conducted in our branch. & 0.629 & Fixed \\
\hline CHA2: In our branch the bank provides us with a high level support service. & 0.639 & $10.548 *$ \\
\hline $\begin{array}{l}\text { CHA3: We take commercial advantage of the various means of distribution at our disposal } \\
\text { (branch, ATMs, Web, etc.). }\end{array}$ & 0.785 & $12.259 *$ \\
\hline CHA4: We distribute our products/services through all the channels available in the sector. & 0.767 & $12.024 *$ \\
\hline Communication capability $(\alpha=0.882 ; \mathrm{CR}=0.88 ; \mathrm{AVE}=0.56)$ & 0.902 & $13.477 *$ \\
\hline $\begin{array}{l}\text { COM1: In our branch we are capable of running the promotion programmes that the bank } \\
\text { launches. }\end{array}$ & 0.676 & Fixed \\
\hline COM2: We have creative skills for commercial promotion. & 0.707 & $12.718 *$ \\
\hline COM3: We have public relations skills. & 0.760 & $13.503 *$ \\
\hline COM4: We have the skills to promote our bank's brand image. & 0.848 & $14.840^{*}$ \\
\hline COM5: In our branch we have the skills to manage our image and reputation in the market. & 0.849 & $14.871 *$ \\
\hline COM6: Our employees have sales skills. & 0.641 & $11.577 *$ \\
\hline \multicolumn{3}{|l|}{ PERFORMANCE $(\alpha=0.841 ; \mathrm{CR}=0.84 ; \mathrm{AVE}=0.58)$} \\
\hline PER1: Volume of sales & 0.769 & $16.948 *$ \\
\hline PER2: Market share & 0.739 & $16.126^{*}$ \\
\hline PER3: Pro & 0.636 & $13.319 *$ \\
\hline PER4: Overall satisfaction & 0.878 & $20.437 *$ \\
\hline
\end{tabular}

Note: Fit of the model: $\chi 2=887.025, \mathrm{df}=532, \chi 2 / \mathrm{df}=1.667 ; \mathrm{RMSEA}=0.042 ; \mathrm{RMR}=0.026 ; \mathrm{CFI}=0.962 ; \mathrm{IFI}=0.963$; $\mathrm{NFI}=0.913 ; \mathrm{NNFI}=0.936 . \mathrm{CR}=$ composite reliability; $\mathrm{AVE}=$ average variance extracted.

$* p<.01$ 
Table 3: Scale discriminant validity

\begin{tabular}{lllll}
\hline & $\mathbf{1}$ & $\mathbf{2}$ & $\mathbf{3}$ & $\mathbf{4}$ \\
\hline 1. Market orientation & 0.93 & & & \\
2. Dynamic capabilities & $0.67^{*}$ & 0.85 & & \\
3. Marketing capabilities & $0.75^{*}$ & $0.79 *$ & 0.82 & \\
4. Performance & $0.43^{*}$ & $0.49^{*}$ & $0.52^{*}$ & 0.76
\end{tabular}

Below the diagonal: correlation estimated between the factors. Diagonal: square root of AVE.

$* p<.01$ 
Table 4: Summary results of the structural model

\begin{tabular}{llcll}
\hline Hypothesis & Path & Parameter & t-value & Results \\
\hline $\mathrm{H}_{1}$ & Market orientation $\rightarrow$ Dynamic capabilities & 0.674 & $8.162^{*}$ & Supported \\
$\mathrm{H}_{2}$ & Market orientation $\rightarrow$ Marketing capabilities & 0.303 & $4.664^{*}$ & Supported \\
$\mathrm{H}_{3}$ & Dynamic capabilities $\rightarrow$ Performance & 0.062 & 0.315 & Supported \\
$\mathrm{H}_{4}$ & Marketing capabilities $\rightarrow$ Performance & 0.472 & $2.566^{*}$ & Supported \\
$\mathrm{H}_{5}$ & Dynamic capabilities $\rightarrow$ Marketing capabilities & 0.717 & $7.014^{*}$ & Supported \\
\hline Note: Fit of the model: $\chi 2=910.591, \mathrm{df}=547, \chi 2 / \mathrm{df}=1.664 ; \mathrm{RMSEA}=0.042 ; \mathrm{RMR}=0.026 ; \mathrm{CFI}=0.961 ; \mathrm{IFI}=0.963 ;$ \\
NFI=0.911; NNFI=0.936. & & & \\
$* p<.01$ & & & &
\end{tabular}


Figure 1: General causal relationships from ambidexterity theory

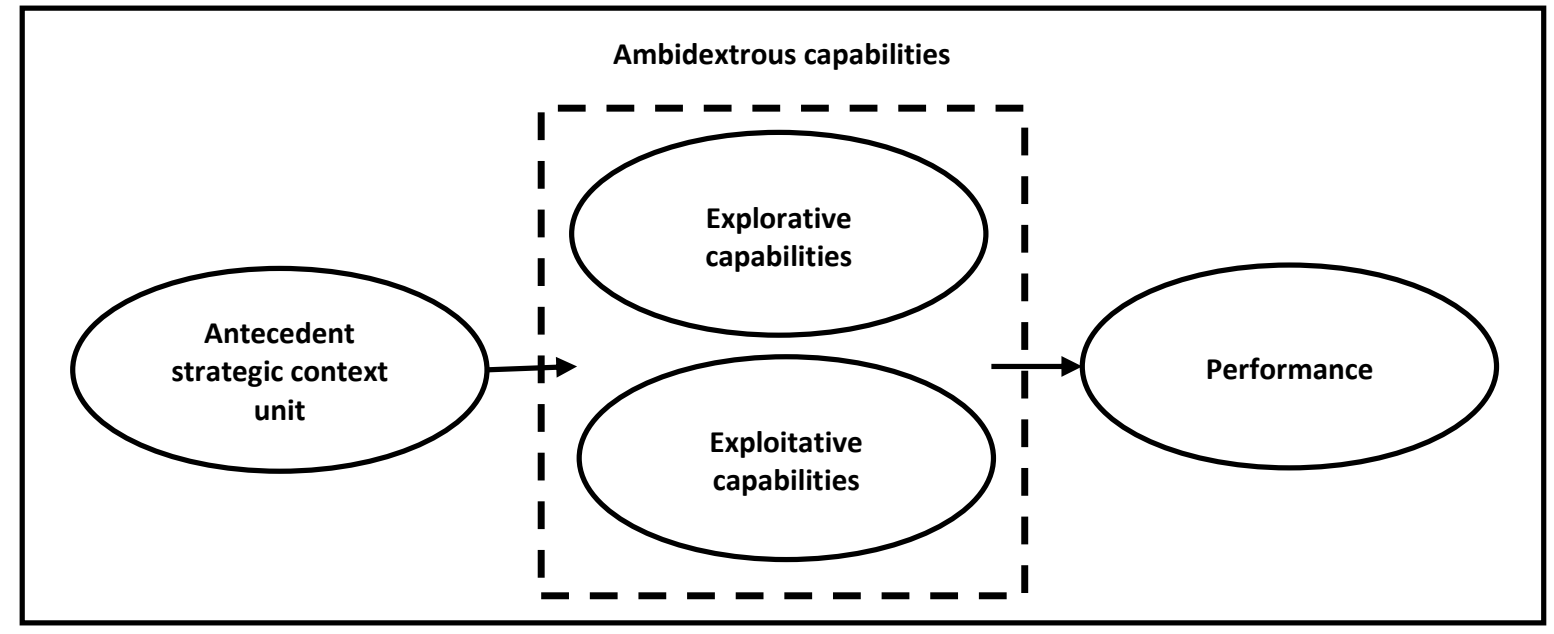


Figure 2: Model of effects

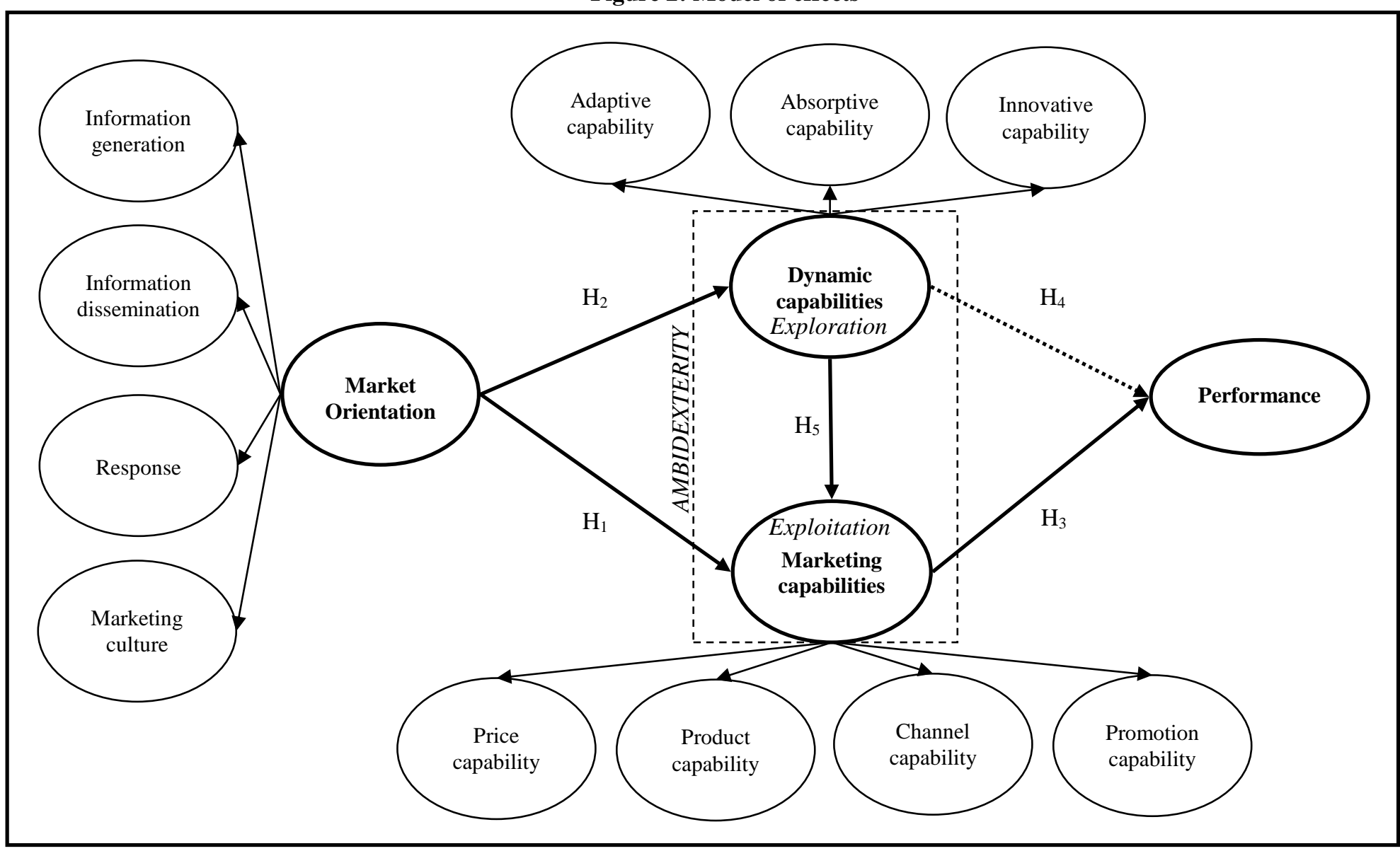

